\title{
Fluxes in litter decomposition in three selected indigenous species and teak in a converted rainforest ecosystem in southwestern Nigeria
}

\author{
A. F Ojo ${ }^{a}$, O. Kadebab and J. Kayode ${ }^{c}$ \\ ${ }^{a}$ Department of Afforestastion, Ministry of Lands, Housing and Environment, Ado - Ekiti, ${ }^{b}$ Department of \\ Forestry and Wood Technology, Federal University of Technology, Akure and ${ }^{c}$ Department of Plant Science, \\ University of Ado-Ekiti, Ado-Ekiti, Nigeria
}

\begin{abstract}
The study investigated the rate of litter decomposition in three prominent litter releasing indigenous tree species in the natural rainforest and an exotic species Teak, Tectona grandis Lim., in the adjacent plantation in Akure forest reserve, southwestern Nigeria. Results showed that teak had the highest litter decomposition rate and Mansonia altissima the least. There was no relationship between the rates of decomposition among all species examined. The implication is that teak litter had the highest probability of releasing litter nutrients into the soil nutrient pool than any of the selected indigenous tree species while Mansonia altissima had the least. However all species had high decomposition rates. This implies that soil fertility will be maintained if any of the tree species were to be used for monoculture plantations.
\end{abstract}

Key words: Fluxes, Litter decomposition, Indigenous species, Converted rainforest ecosystem, Nigeria.

\section{Introduction}

In the tropics, most of the recycling nutrients depend on the amount of litter on the forest floor. The production of such litter and its subsequent decomposition play a major role in the transfer of energy and nutrient in such forests (Songwe, 1984). Apart from adding large organic materials into the soil, nutrient addition from litter strongly influence both the physical and chemical properties of soil in such ecosystems (Upadhay and Singh, 1989). Okeke and Omaliko (1992) reported that effective recycling of nutrients from litter decomposition greatly influenced soil fertility at Ozala in southeastern Nigeria. Usually, such nutrients may enter the mineral soil before being taken up by plants. In some cases, this may not be so. For instance, Stark and Jurdan (1978) reported that inorganic materials from the litter had been known not to enter the mineral soil pool before being taken up by plant roots in the Amazonian rainforest of Brazil.

Replacement of natural ecosystems by monoculture plantations have been known to affect the rate of litter decomposition from location to location. For instance, Sankaran et al (1993) observed that in many plantation species e.g. Eualyptus, Pines and Casuarina spesies, decomposition was lower than in their adjacent natural forests. On the contrary, Evans (1992) reported an annual decomposition rate of between $0.3-5.3$ and $0.11-2.0$ in the natural tropical forests and forest plantations respectively. This implies that the type of monoculture plantation emerging from converted natural forests will have impacts on the rate of decomposition of their litter.

This study was therefore initiated to investigate and compare the intra- and inter - species differences in the rate of decomposition among the three indigenous species and between the indigenous and exotic species in the converted rainforest ecosystem in Akure forest reserve in southwestern Nigeria. This is with a view to ascertaining the nutrient contribution of prominent indigenous species to the ecosystem and the changes of such rate of litter decomposition if such an ecosystem is converted to a monoculture plantation.

\section{Materials and Methods}

\section{The Study Area}

The study was conducted in the Permanent Sample Plot, PSP No 29 strictly reserved for research purposes by the Forestry Research Institute of Nigeria, FRIN, Ibadan and the adjacent 16-year old teak plantation owned by the Ondo State Government in Akure forest reserve. The area lies along latitude $7^{\circ} 18^{1} \mathrm{~N}$ and longitude $5^{\circ} 02^{1} \mathrm{E}$ (Jones, 1948) and on an altitude of $250 \mathrm{~m}$ above the sea level (Fagbenro and 
Onweluzo 1976, Ola-Adams and Hall 1987). The climate is humid tropical (Thornthwaite, 1948) with seasonal variation. The mean annual rainfall is about $1.500 \mathrm{~mm}$ with double maxima in the months of July and September and a short relatively dry period in August. The relative humidity at 15 hours GMT is highest in the maxima months and lowest in February at about 81 and 44 percent respectively (Fagbenro et al 1976). Temperature ranges from about $20.6^{\circ} \mathrm{C}$ to 33.5 ${ }^{\circ} \mathrm{C}$. The monthly mean temperature is about $27{ }^{\circ} \mathrm{C}$ a condition that is conducive to the development of the tropical rainforests and plantations. The vegetation is lowland rainforest.

The area is gently undulating and plain. The underlying rock, which is gnesiss is crystalline as found in the basement complex. As a result of continuous weathering the ferruginous (ferric luvisol) tropical soils which feature prominently in many upland parts of southwestern Nigeria is also present in Akure forest reserve (FAO/UNESCO 1977).

\section{Laying of plots}

Two experimental sites representing two contrasting ecosystems (natural rainforest and teak plantation) but with similar soil and site conditions were selected adjacent to each other on a level (slope less than 5\%) land at the southern end of Akure forest reserve. In each of the ecosystems, a study plot, $0.25 \mathrm{ha}(50 \mathrm{~m} \times 50 \mathrm{~m})$ was demarcated. Each plot was further sub - divided into twenty - five $10 \mathrm{~m}$ x $10 \mathrm{~m}$ sub - plots.

\section{Field Experiment}

Nylon litterbag technique was used to quantify the kinetics of litter decay in the plots by determining weight loss during decomposition. Leaves and twigs of the three most litter producing tree species of Mansonia altissima, Triplochiton scleroxylon and Myrianthus arboreus from the natural forest and Tectona grandis from the plantation were put in $20 \mathrm{~cm} \times 20$ litter bags in the filed. Each species sample was replicated three times. Their rates of decomposition were monitored at $2,4,8,16,32$ and 40 weeks.

Mansonia altissima and Triplochiton scleroxylon were valuable indigenous timber species. These are currently being used for plantation establishment in Nigeria because of their relatively faster growth rate over other high grade indigenous timber species. Tectona grandis is a high-grade industrial timber species which has for about a century thrived well in most Nigeria tropical forests. Myrianthus arboreus is an under storey non - timber species. However, its profuse branching system and relative fast growth and heavy leaf abscission and litterfall mostly in the rainy season makes it a valuable fuelwood and source of soil nutrient replenishment species respectively. It could also be tried in monoculture plantation.

Fresh leaves and twigs (small branches) of selected species were oven - dried for 48 hours at $70{ }^{\circ} \mathrm{C}$ to remove moisture and bring all samples to content weight. Eighteen $20 \mathrm{~cm} \times 20$ $\mathrm{cm} 2 \mathrm{~mm}$ nylon litter bags were each filled with about $10 \mathrm{~g}$ oven - dried leaf or twig for each species. Samples were randomly positioned in the corresponding vegetation i.e. natural forest and teak plantation. All samples were rested on the forest floor devoid of litter so that they were in direct contact with the forest floor.

Litter bags were randomly distributed in the corresponding plots and harvesting of such samples was made at 2, 4, 8, 16, 32 and 40 weeks.

\section{Determination of the decomposition constant, $k$}

The decomposition rate or constant, $k$ was determined from the regression equation,

$\operatorname{Ln} Y_{1}=Y_{0} \exp (-k t)$ where

$\mathrm{Y}_{1} \quad=$ percentage of litter remaining $(\mathrm{g})$ at time $t$

$\mathrm{Y}_{0} \quad=$ original weight of litter $(\mathrm{g})$

$\exp =$ exponential

$\mathrm{t} \quad=$ time in weeks

$\mathrm{k}=$ decomposition rate

$\mathrm{Ln} \quad=$ natural $\log$

Yi was regressed against t. Subsequently the level of significance was tested using the F distribution and LSD method (Olson, 1963).

\section{Results and Discussion}

\section{Decomposition of litter}

The percentage decomposition of all samples is as shown in Table I. There was a high initial weight loss in all species components before 2 weeks except in Mansonia altissima leaf and twig. Between $4-8$ weeks, only Triplochiton scleroxylon twig and Myrianthus arboreus leaf had weight reductions. At 16 weeks there were high weight losses in Triplochiton sceleroxylon and Tectona grandis leaf and twig. Myrianthus arboreus weight losses continued to manifest in all samples except Mansonia twig as well as Myrianthus arboreus and Triplochiton scleroxylon twigs at 32 weeks. 
Table I: Percentage decomposition of litter of three prominent tree species and teak in Akure forest reserve

\begin{tabular}{lcccccccc}
\hline & \multicolumn{7}{c}{ Samples } \\
\hline Time in Weeks & $\mathrm{A}_{1}$ & $\mathrm{~A}_{2}$ & $\mathrm{~B}_{1}$ & $\mathrm{~B}_{2}$ & $\mathrm{C}_{1}$ & $\mathrm{C}_{2}$ & $\mathrm{D}_{1}$ & $\mathrm{D}_{2}$ \\
\hline 2 & 98.31 & 84.11 & 79.70 & 77.21 & 78.06 & 75.33 & 76.04 & 74.82 \\
4 & 96.01 & 73.11 & 74.32 & 64.18 & 74.49 & 74.36 & 71.09 & 67.24 \\
8 & 86.82 & 70.56 & 68.34 & 49.14 & 49.48 & 51.04 & 65.71 & 66.55 \\
16 & 64.90 & 25.02 & 3.93 & 28.84 & 20.90 & 42.79 & 0.40 & 6.38 \\
32 & 17.46 & 22.50 & 0.00 & 27.92 & 0.00 & 21.88 & 0.00 & 0.00 \\
40 & 6.37 & 21.50 & 0.00 & 7.51 & 0.00 & 0.00 & 0.00 & 0.00 \\
\hline
\end{tabular}

$\mathrm{A}=$ Mansonia altissima $; \mathrm{B}=$ Myrianthus arboreus $; \mathrm{C}=$ Triplochiton scleroxylon; $\mathrm{D}=$ Tectona grandis $($ Teak $) ; 1=1$ leaf $2=$ twig

During this period, leaves of Myrianthus arboreus and Triplochiton scleroxylon and both the leaf and twig of Tectona grandis had decomposed completely. At 40 weeks. Triplochiton scleroxylon twig decomposed completely while there were substantial weight reductions in Mansonia altissima leaf and Myrianthus arboreus twig but Mansonia altissina twig had no substantial reduction in weight. At the end of experiment, three samples, Mansone altssima leaf and twig and Myrianthus arboreus twig did not decomposed completely. Tectonia grandis leaf and twig decomposed faster than all the species from the natural rainforest.

Decomposition constants, $k$

The decomposition constant, $\mathrm{k}$ for all samples is as shown in Table II. Statistical analysis carried out separately on all samples is as shown in Table III. The table also showed that only Mansonia altissima leaf had a significant decomposition constant, $k$ value from the other three species. Differences among all other leaf samples were minor. The differences in the rate of decomposition of twigs in all the four species were not statistically significant.

Table II: Annual Decomposition Constants, $k\left(\mathrm{yr}^{-1}\right)$ for three prominent tree species and teak in Akure forest reserve

\begin{tabular}{lcc}
\hline Species & \multicolumn{2}{c}{ Decomposition constants } \\
\cline { 2 - 3 } & \multicolumn{2}{c}{$\mathrm{K}^{\left(\mathrm{yr}^{-1}\right)}$} \\
\cline { 2 - 3 } & Leaf & Twig \\
\hline Mansonia altissima & 2.059 & 3.172 \\
Myrianthus arboreus & 4.888 & 4.264 \\
Triplochiton sceleroxylon & 4.961 & 3.692 \\
Tectona grandis (Teak) & 5.200 & 5.044 \\
\hline
\end{tabular}

The rate of decomposition of litter is a function of three regulatory factors, the physical environment, the resource (lit- ter) quality and the decomposer organism (Swift et al 1981). The resource quality is the most important factor controlling the decomposition of organic materials in this study since the physical environment and decomposer organisms are likely to be constant to the two ecosystems. The degree of lignification, nutrient composition process (Swift and Anderson, 1989) is factors which could have influenced the same process in the study area.

The resource (litter) quality of trees differs from one species to another. This may result in intra - species difference in decomposition rates. The decomposer organisms differ in number, species and preference for the resources being decomposed. The intersite difference in decomposition between the natural forest trees and the teak in the plantation is therefore expected.

The terminal differences in weight loss in tree leaves and twigs were noted in this study. For instance, the rapid decomposition of litter of species at the initial stage of the study i.e. between $2-4$ weeks may be due to the initial higher content of water - soluble materials being actively broken down by decomposer organisms. It is possible that the lignin content of species was one of the factors that determine the rate of decomposition of various species leaves and twigs over time. Russel (1973) has reported that lignin can render some of the cellulose and the other constituents inaccessible to the microflora. The probable abundance of such lignin content in the leaf of Mansonia altissima must have been responsible for its significant difference in its decomposition rate to the other species leaf samples. 
Table III: Statistical analysis of fluxes Litter decomposition of selected tree species in Akure forest reserve.

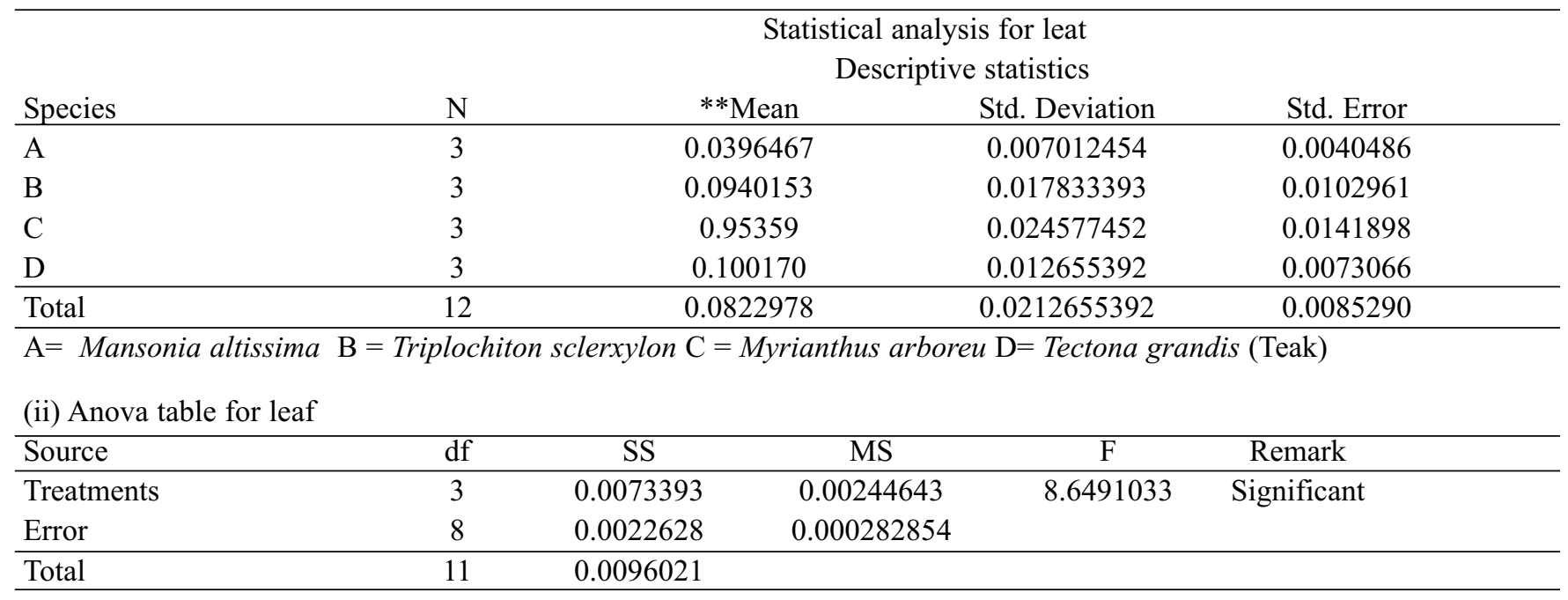

(i) Result of LSD Test

Species Means

$\begin{array}{ll}\text { A } & 0.039647^{\mathrm{a}} \\ \text { B } & 0.094015^{\mathrm{b}} \\ \text { C } & 0.095359^{\mathrm{b}} \\ \text { D } & 0.100170^{\mathrm{b}}\end{array}$

* Means followed by the same superscript are not statistically different $(\mathrm{p}>0.05)$

Significant $\mathrm{F}$ at $5 \%=4.07$

(ii) Statistical analysis for twig

Descriptive Statistics

\begin{tabular}{lcccc}
\hline Species & $\mathrm{N}$ & Mean & Std. Deviation & Std. Error \\
\hline $\mathrm{A}$ & 3 & 0.060872 & 0.024855268 & 0.0143502 \\
$\mathrm{~B}$ & 3 & 0.081910 & 0.04432214 & 0.0255894 \\
$\mathrm{C}$ & 3 & 0.095339 & 0.024618888 & 0.0142137 \\
$\mathrm{D}$ & 3 & 0.097446 & 0.013835304 & 0.0079878 \\
\hline Total & 12 & 0.0779135 & 0.028523495 & 0.0082340 \\
\hline
\end{tabular}

(ii) ANOVA table for twing

\begin{tabular}{lccccc}
\hline Source & df & SS & MS & F & Remark \\
\hline Treatments & 3 & 0.00219 & 0.000730001 & 0.8639729 & Not Significant \\
Error & 8 & 0.0067595 & & 0.000844935 & \\
\hline Total & 11 & 0.0089495 & & & \\
\hline
\end{tabular}

** Mean of Sample replicates

The order of decomposition in the four species was Tectona grandis (teak) $>$ Triplochiton scleroxylon $>$ Myrianthus arboreus $>$ Mansonia altissima for the leaf samples and Tectona gradis $>$ arboreus $>$ Triplochiton scleroxylon $>$ Mansonia altissima for the twig. Since there is usually more leaf component than any other components in litterfall (Ojo, 2005), it is likely to contribute the greatest amount of nutri ent to the soil nutrient pool from litterfall.
Tectona grandis has the highest decomposition rate among the considered species and Mansonia altissima had the least. Since the probable lignin content and/or inhibiting materials are synonymous with the rate of decomposition and subsequent nutrient content contribution to the soil nutrient reserve, teak will keep the soil nutrient level more constant than any other species in a monoculture plantation all other conditions kept constant Mansonia altissima litter may have 
a relatively less chance of soil nutrient level enhancement under plantation conditions. It is evident that decomposition rates differ among species and with changes in climatic conditions. Nutrient addition to the soil through the amount of litterfall will depend on such decomposition rates especially in the tropics.

It was observed that decomposition rates were relatively high for all selected species in the study area. This confirms the results from other tropical forests (Table IV) that tropical forests have relatively high decomposition rates. Such high rates was said to be due to high prevalence of favourable conditions for microbial activity.

Cuevas and Medina (1988) postulated that the time required for the decomposition of at least $95 \%$ of initial litter biomass in any decomposition process was $3 / k$ if $\mathrm{k}$ is the annual decomposition constant. This means it will take 0.6 year for about $95 \%$ of the teak biomass to decay while it will take between 0.6 and 1.5 years for at least $95 \%$ of the initial litter biomass to decompose in the selected species in the high forest. This implies that depending on the amount, the pattern and the physical environment of litterfall in an area, more nutrients will return to the soil nutrient pool in the teak plantation than any of the indigenous trees in the high forest. On the other hand, nutrient shortfall may arise from the plantation in the long run if trees were massively removed at harvest. This may lead to land degradation as a result of erosion. A quick replacement of harvested trees may therefore be necessary since the amount of nutrient taken up by harvested trees is relatively too small to adversely affect the level of the stored nutrient in the soil.

Table IV: Selected values of decomposition constants for humid tropical forests $\left(3 / \mathrm{k}^{*}\right)$ time required for $95 \%$ loss of initial liter biomass

\begin{tabular}{llll}
\hline Locality & $\mathrm{k}$ years & $3 / \mathrm{k}$ years & Source \\
\hline Summart for some tropical forests worldwide & $1-4$ & $0.7-3.0$ & Olson (1963) \\
Humid forest on latosol,Colombia & 0.4 & 705 & Foelsteer and de la Salas (1976) \\
Leaves of Eperua falcate, French Guiana & 0.5 & 6.0 & Kiffer et al, (1981) \\
Banco forest & & & Bemhard Reversat (1972)
\end{tabular}

lvory Coast

lsolated species

$\begin{array}{llll}\text { i. } & \text { Forest } & 3.2-7.5 & 0.4-0.9 \\ \text { ii. } & \text { Plateau } & 3.3 & 0.9 \\ \text { iii. } & \text { Talweg } & 4.2 & 0.7\end{array}$

Sarawk forests

$\begin{array}{lll}\text { i. } & \text { Alluvial } & 1.7 \\ \text { ii. } & \text { Dipterocarp } & 1.7 \\ \text { iii. } & \text { Heath } & 1.4\end{array}$

Flooded forests, manaos

$\begin{array}{llll}\text { i. } & \text { Eschweilera coriaceo } & 2 & 1.40 \\ \text { ii. } & \text { Buchenavia ochrosperm a } & 2.9 & 1.0 \\ \text { iii. } & \text { fresh litter lgapo } & 0.48 & 6.2 \\ \text { iv. } & \text { varzea } & 1.08 & 2.8 \\ \text { Mamos } & 1.3 & 2.3 \\ \text { Rio Negro, Tall Amazon Caatinga } & 0.87 & 3.4 \\ \text { Rio Negro, Venezuela } & & \\ \text { i. } & \text { Tierra Firme } & 0.58-5.00 & 0.6-5.2 \\ \text { ii. } & \text { Tall Amazon Castinga } & 0.80-1.33 & 2.3-3.8 \\ \text { iii. } & \text { Vana } & 0.22-0.44 & 6.8-13.6\end{array}$

Akure Forest Reserve, Nigeria

i Selected species in the natural forest

$2.06-5.0 \quad 0.6-1.5$

ii Tectona grandis plantation

5.12

Klings (1977)

Herrera (1979)

Cuevas and Medina (1988)

Present study

* = suggested by Cuevas and Medina (1988) 
In conclusion, the result of this study implies that if the stock of all species in the study is kept constant in the establishment of monoculture plantation, Tectona grandis stands the best chance of contributing nutrients to the soil nutrient pool through the decomposition of its litter and Mansonia ultissi$m a$, the least. Consequently, Tectona grandis, Triplochiton scleroxylon, Myrianthus arboreus and Mansonia altissima will enhance soil fertility in diminishing order if each of the species is established in monoculture plantations under the same soil, site and climatic conditions. However, any of them will still not deplete the soil if established as monoculture plantations because of their relatively high decomposition rates.

\section{References}

Cuevas E and Madina E (1988). Nutrient dynamics within Amazonian Forests II. Fine root growth, nutrient availability and nutrient leaf litter decomposition, Oecologia 76: 222- 235.

Evans J (1992). Plantation Forestry in the tropics Clarendom Press, Oxford, 403p.

Fagbenro JA and Onweluzo BSK (1976). Soil studies in Akure Forest Reserve. Paper presented at the 7th Annual Conference of the Forestry Association of Nigeria Nov, 20 - 27, 1976, Kano. Nigeria 27p.

Fagbenro JA, Orimayegun SO, Aluko AP and Daramola DS (1976). Assessment of biomass production, coppicing and nitrogen fixing capabilities of some nitrogen fixing legume tress in two Nigeria soils. Paper presented at a Conference held at the Forestry Research Institute of Nigeria, Ibadan 23p.

FAO/UNESCO (1977). Soil Map of the World 1:5, 000,000. Vol VI Africa, UNESCO Paris.

Jones APD (1948). The Natural Forest Inviolate Plot. The Nigerian Forest Service Publication, Ibadan.

Ojo AF (2005). Organic matter and nutrient dynamics in the natural rainforest and teak plantation in Akure Forest Reserve, Nigeria. Unpublished PhD Thesis, Federal University of Technology, Akure, Nigeria. 130p.

Okeke AI and Omeliko CPE (1992). Leaf litter decomposition and carbon dioxide evolution in some agroforestry fallow species in southern Nigeria. Forestry Ecology and Management 50: 103 - 116.
Ola - Adams BA and Hall JB (1987). Soil plant relations in a natural forest inviolate plot at Akure, Nigeria. Journal of Tropical Ecology 3: 57-74.

Olson JS (1963). Energy storage and balance of products and decomposers in ecological systems. Ecology 44: 323351 .

Russel EW (1973). Soil condition and plant growth Longmans Green \& Co . London 688p.

Suakaran KV, Balasundaran M, Thomas TP and Sujatha MP (1993). Litter dynamics, Microbial association and soil studies. Acacia auriculiforms plantation in Kerala Research Report No. 91 KFRI, Kerala, India. 56p.

Songwe NC (1984). Litter production and decomposition in a tropical rainforest in southern Bukundu Forest Reserve, Cameroon. Unpublish $\mathrm{PhD}$ Thesis, University of Ibadan, Nigeria. 296p.

Stark NM and Jordan CF (1978). Nutrient retention by the root mat of an Amazonian rainforest, Ecol. 59: 434 437.

Swift MJ and Anderson JM (1989). Decomposition. Pp. 547 - 569. In: Lieth, A. and Werger, M.J.A (Eds.). Tropical rainforest ecosystems: Ecosystem of the World 14 Elsevier, Amsterdam.

Swift MJ, Ward HO and Anderson JM (1979). Decomposition in terrestrial ecosystems. Blackwell, Oxford, 372 p.

Thornthwaite CW (1948). An approach towards a national classification on climate, Geographical Review 38: 3554.

Tiessen H, Cuevas E and Checon P (1994). The role of soil organic matter in sustaining soil fertility, Nature 371: $783-785$.

Upadhya BP and Singh JS (1989). Pattern of nutrient immobilization and release in decomposing forest litter in Central Himalaya, India Journal of Ecosystem 77: 127 $-146$

Received: 10 April 2011; Revised : 14 July 2011; Accepted: 19 July 2011 . 